\title{
Slik unngår du nettbrettnakke
}

\author{
Nettbrettnakke, tekstnakke eller iPad-nakke? Hva du enn kaller det - \\ vi har samlet noen råd om hvordan du unngår fenomenet.
}

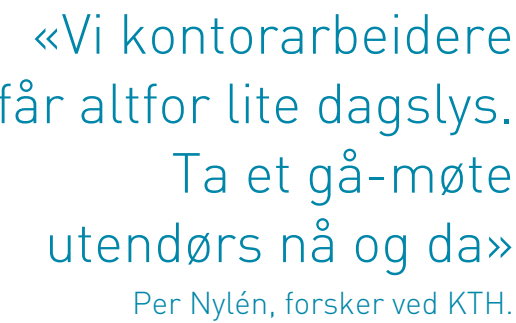

Enten du er fastlege, professor eller turnuslege, innebærer trolig en stor del av jobben din skjermarbeid. På bussen hjem må du dessuten sjekke e-post og Facebook på mobilen og når du kommer hjem venter sofaen og nettbrettet. Slik atferd kan gi muskelspenninger og smerteplager i nakke og skuldre, som igjen kan føre til hodepine og svimmelhet. Vinkelen har skylden, ifølge Harvard Health Letter (1).

- Jo lengre ned i fanget nettbrettet er, desto mer må du bøye nakken for å nå ned til det, sier Jack Dennerlein ved Harvard School of Public Health.

Muskler, nerver, sener, ligamenter og nakkevirvler blir strukket og utsatt for skadelig belastning. Også bruk av stasjonær datamaskin kan gi de samme plagene.

Per Nylén, forsker ved Kungliga Tekniska högskolan i Stockholm, forteller til Personal \& Ledarskap at mange nettbrettnakker oppstår fordi vi vil se bedre (2).
Om teksten eller bildene er uklare, bøyer vi oss fremover og spenner nakke og skuldre ytterligere.

Her er noen av Nylén og Dennerleins tips mot nettbrettnakke.

1. Plasser nettbrettet i et stativ eller på en støtte, slik at vinkelen blir bedre.

2. Legg bort de progressive brillene.

3. Øk tekststørrelsen.

4. Velg heller matt enn blank skjerm.

5. Ikke bruk brett mer enn to timer per dag.

6. Viktigst av alt: Skift stilling hvert kvarter, og ta pauser.

\section{Eline Feiring}

Tidsskriftet

\section{Litteratur}

1. Harvard Health Letter. 6 tips to prevent neckshoulder pain when using an ipad or computer http://health.harvard.edu/press_releases/ 6-tips-to-prevent-neck-shoulder-pain-whenusing-an-ipad-or-computer (10.3. 2014).

2. Personal \& Ledarskap. Så slipper du gamnacke. http://personalledarskap.se/nyheter/ sa-slipper-du-gamnacke/33377.pl (10.3. 2014)

\section{Pris til Randi Ulberg for klinisk psykiatrisk forskning}

Randi Ulberg (f. 1962), overlege ved Klinikk psykisk helse og rusbehandling ved Sykehuset i Vestfold, er tildelt pris fra «Solveig og Johan P. Sommers stiftelse til fremme av fremragende klinisk psykiatrisk forskning» for 2014.

Stiftelsen deler årlig ut en pris for et publisert arbeid som representerer nyvinnende, klinikknær og fremragende klinisk psykiatrisk forskning.

Ulberg mottar prisen for artikkelen Women respond more favorably to transference intervention than men; a randomized study of long-term effects som i 2012 ble publisert i Journal of Nervous and Mental Disease.

Artikkelen viser at kvinnelige pasienter har mer nytte enn menn av intervensjoner fra legen.

- Grunnen til at Solveig og Johan P. Sommers stiftelse i år har gitt prisen til Randi Ulberg er fordi mulige forskjeller mellom kjønnene når det gjelder effekt av psykoterapi, er et område som det er forsket lite på. Det er derfor svært viktig at dette undersøkes med gode empiriske metoder og design, sier professor emeritus Lars Weisæth.

- Psykoterapiforskningen ved Universitetet i Oslo har en lang tradisjon. Randi Ulberg tilhører den neste generasjon forskere som er tilknyttet dette forskningsmiljøet, og vi håper prisen vil oppmuntre til videre forskning.

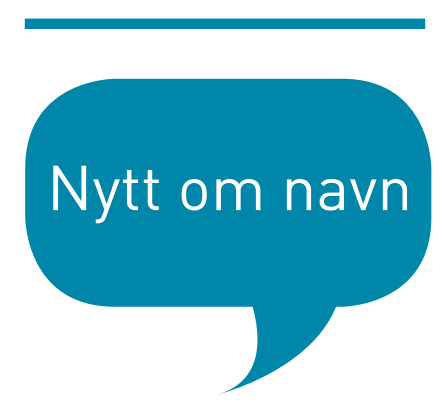

Thy Thy Vanem

er klinisk stipendiat ved Oslo universitetssykehus og vil nå starte en ny forskningsstudie for å kartlegge hvordan det har gått med de 105 deltakerne i Norsk studie om Marfans syndrom, ti år etter at de sist ble undersøkt. Studien bygger på funnene i Svend Rand Hendriksens doktorgradsstudie om diagnosen. (Sunnaas sykehus)

Jonas Kinge Bergland

er lege og for tiden aktuell med stand-up-showet Dr. Bergland og den alternative medisin på Latter i Oslo. Han bruker ofte sin medisinske bakgrunn på scenen. (Latter.no)

\section{Mina Adampour}

er snart ferdig utdannet lege, et ønske hun har hatt hele livet. Hun ble rådet til å velge yrkesfag på ungdomsskolen, og da hun på videregående fortalte rådgiveren at hun ønsket å studere medisin, var rådet å dempe sine ambisjoner og heller bli helsesøster. (Aftenposten) 